\title{
Miasto odporne - rozbudowa tkanki współczesnego miasta na podstawie projektów powtarzalnych
}

\section{Resilient city - tissue development of a modern city based on repeatable projects}

\section{Streszczenie}

Artykuł porusza kwestię zastosowania projektów typowych/powtarzalnych w kształtowaniu stref podmiejskich współczesnych miast w kontekście realizacji koncepcji „miasta odpornego” - na przykładzie rozwoju współczesnego Krakowa. Obecny dynamiczny rozwój strefy podmiejskiej wymusza bowiem wprowadzanie rozwiązań, stanowiących odpowiedź na zagrożenia współczesnej rzeczywistości oraz na aktualne potrzeby społeczne, takich jak: kompaktowa zabudowa mieszkaniowa, zorganizowany i racjonalny rozwój układu komunikacyjnego oraz dążenie do samowystarczalności nowo realizowanej zabudowy na podstawie zasobów lokalnych. Artykuł obejmuje również analizę korzyści i zagrożeń wynikających z zastosowania w realizowanej obecnie zabudowie podmiejskiej projektów „gotowych”. Jako potencjalne zagrożenia wskazuje możliwość pozbawienia tożsamości lokalnej danego miejsca poprzez wprowadzenie nowej architektury i nowych typów zabudowy w istniejącą, tradycyjną tkankę urbanistyczną, jak również możliwą unifikację zabudowy i „nijakość” architektury. Podkreśla też zalety zastosowania projektów powtarzalnych: skrócenie procesu projektowego i inwestycyjnego do niezbędnego minimum, co przekłada się na wzrost dynamiki rozwoju rynku budownictwa mieszkaniowego, wymuszoną wymaganiami rynku i zmianami w prawie ewolucję projektów typowych, która stanowi swoisty poligon do wprowadzania nowych technologii, uniwersalność projektów typowych umożliwiającą tworzenie różnych wariantów stylistycznych na bazie jednego układu funkcjonalnego oraz kompaktowość umożliwiającą racjonalne i uporządkowane organizowanie przestrzeni strefy podmiejskiej.

Słowa kluczowe: miasto odporne, projekty typowe, projekty powtarzalne, projekty katalogowe, zabudowa mieszkaniowa jednorodzinna, zabudowa strefy podmiejskiej 


\begin{abstract}
The article discusses the issue of applying typical, repetitive projects in shaping suburban zones of modern cities in the context of implementing the concept of a resilient city - on the example of the development of contemporary Kraków. The current dynamic development of the suburban area requires the introduction of solutions - responding to the threats of contemporary reality and current social needs - such as: compacting residential buildings, organized and rational development of the transport system and trend for self-sufficiency of the newly implemented buildings based on local resources. The article also includes an analysis of the benefits and risks of applying ready-made projects in the suburban housing development currently underway. As potential threats, indicates the possibility of depriving the local identity of a given place by introducing new architecture and new types of buildings into the existing, traditional urban fabric, as well as the possible unification of buildings and the inexpression of architecture. It also accent the advantages of using repetitive projects: shortening the design and investment process to the necessary minimum - which translates into an increase in the dynamics of the housing market development, forced by market requirements and changes in law, the evolution of typical projects, which is a specific training ground for the introduction of new technologies, the versatility of typical projects enabling the creation of various stylistic variants on the basis of one functional layout and compactness enabling rational and orderly organization of the space of the suburban area.
\end{abstract}

Keywords: resilient city, typical projects, repeatable projects, catalog projects, single-family housing, development in the suburban area 


\section{WSTĘP}

Proces dynamicznego rozwoju stref podmiejskich współczesnych miast, który obecnie obserwujemy, kształtowany jest głównie przez zabudowę jednorodzinną, realizowaną zarówno przez indywidualnych inwestorów, jak też przez prywatnych przedsiębiorców, realizujących w ramach działalności gospodarczej budownictwo jednorodzinne w zorganizowanych zespołach mieszkaniowych. Większość powstającej obecnie jednorodzinnej zabudowy mieszkaniowej w strefie podmiejskiej realizowana jest z zastosowaniem projektów powtarzalnych (tzw. gotowych), które budzą w środowisku architektów skrajne emocje i oceny. Jednak coraz szersze zastosowanie projektów gotowych (powtarzalnych) wydaje się być procesem nieuniknionym, ponieważ ze względu na dynamikę procesu rozbudowy przedmieść współczesnych miast istotnym czynnikiem stała się możliwość zaspokojenia zapotrzebowania rynku inwestycji mieszkaniowych, stanowiącego odpowiedź na zapotrzebowania społeczne. Co za tym idzie - ważnym czynnikiem jest skrócenie do minimum procesu przygotowania i realizacji inwestycji, co umożliwia opracowanie dokumentacji projektowej na podstawie gotowych projektów powtarzalnych. Ponadto projekty gotowe, dzięki coraz szerszemu stosowaniu w nich przez projektantów - przy stosunkowo niskich kosztach projektowych - nowoczesnych rozwiązań oraz technologii proekologicznych, poprzez swoją uniwersalność, samowystarczalność oraz wynikającą z założeń projektowych ekonomikę realizacji służyć mogą realizacji koncepcji miasta odpornego.

\section{PRZYCZYNY I PROCESY POWSTAWANIA MIASTA JAKO FORMY ORGANIZACJI SPOŁECZNEJ JAKO ODPOWIEDZI NA ISTNIEJĄCE POTRZEBY ORAZ ZAGROŻENIA SPOŁECZNE}

Analizując historię naszej cywilizacji - nie tylko europejskiej - wskazać należy, iż od początku jej istnienia miał miejsce proces grupowania się społeczności i tworzenia przez nie zorganizowanych form społeczno-gospodarczych, czego konsekwencją stał się również proces tworzenia organizmów miejskich. Proces ten stanowił odpowiedź na istniejące w każdym z okresów rozwoju cywilizacji określone potrzeby oraz zagrożenia społeczne. Począwszy od greckich państw-miast (polis), stanowiących samodzielne i autonomiczne społeczności o w pełni zorganizowanej strukturze społecznej i gospodarczej, poprzez rzymskie obozy wojskowe (castrum), które stanowiły bazę dla rzymskich podbojów militarnych, ale i przyczyniły się również do wprowadzenia Pax Romana i rozprzestrzenienia się kultury rzymskiej na terenie Europy, dając jednocześnie w późniejszych okresach początek wielu europejskim metropoliom (jak np. Paryż, Wiedeń, Kolonia czy Londyn) po miasta powstałe w okresie nowożytnym (od średniowiecznych ufortyfikowanych grodów obronnych, poprzez renesansowe i barokowe miasta idealne aż po XIX-wieczne miasta twierdze) - zawsze u podstaw 
procesu tworzenia i rozwoju miast stała realizacja istniejących w danym okresie potrzeb społecznych i gospodarczych oraz konieczność zapobiegania istniejącym wówczas zagrożeniom społecznym. Zasadna będzie więc teza, że idea „miasta odpornego” nie jest wynalazkiem czasów współczesnych - od zarania cywilizacji proces powstawania i ewolucji miast stanowił naturalną konsekwencję tworzenia się zorganizowanych i coraz bardziej złożonych form społeczno-gospodarczych oraz miał na celu realizację określonych funkcji, umożliwiających przetrwanie oraz zapewnienie bezpieczeństwa, rozwoju gospodarczego i ekonomicznego populacji miasta w obliczu zmieniających się w czasie potrzeb i zagrożeń (il. 1).

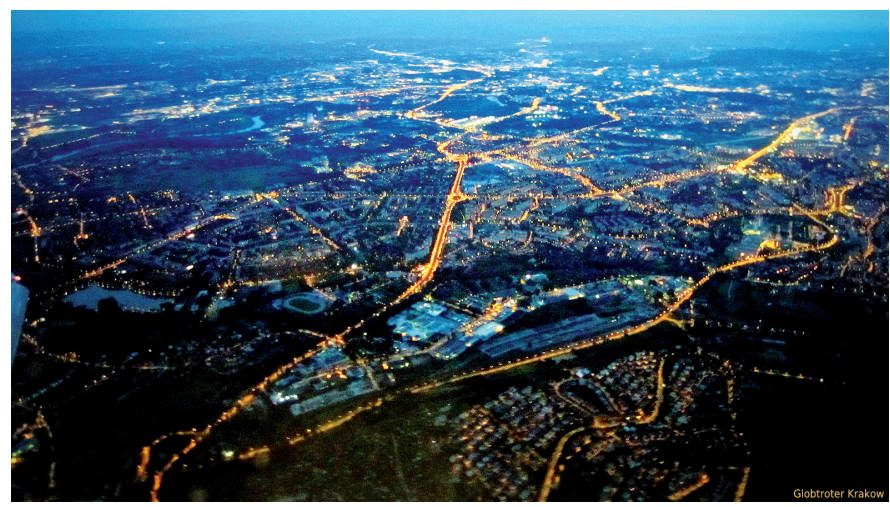

II. 1. Współczesne miasto jako organizm - Kraków z lotu ptaka (http://blog.globtroter-krakow.com/)

Ewolucja współczesnych miast również opiera się na procesach i założeniach, które mają na celu dostosowanie jego funkcji do zmieniającej się dynamicznie rzeczywistości i pojawiających się ciągle nowych potrzebach społecznych oraz zagrożeń. Wrócić więc należy do postawionych wcześniej pytań - czym powinno charakteryzować się miasto odporne? jakimi cechami winno się charakteryzować?

\section{MIASTO ODPORNE - DEFINICJA I CECHY MIASTA ODPORNEGO}

Koncepcja „miasta odpornego” (urban resilience) powstała jako konsekwencja rozwoju powstałej w II połowie XX w. teorii systemów Ludwiga von Bertalanffy’ego, której głównym założeniem jest analiza i zdefiniowanie elementów składowych systemów społeczno-gospodarczych, pozostających ze sobą w funkcjonalnej więzi. Teoria ta znalazła odzwierciedlenie nie tylko w naukach społecznych (socjologii i politologii), przyrodniczych (ekologia) oraz ekonomicznych, ale również w urbanistyce. W literaturze naukowej koncepcja miasta odpornego (urban resilience) sformułowana została po raz pierwszy w artykule Crawforda S. Hollinga Odporność i stabilność 
systemów ekologicznych opublikowanym w 1973 r. W publikacji tej pojęcie odporności określonego ekosystemu (w szczególności - ekosystemu miejskiego) autor zdefiniował jako zdolność do zachowania - w przypadku pojawienia się określonych zagrożeń i zakłóceń - jego podstawowych elementów składowych i funkcjonalnych, pozostających ze sobą we wzajemnych powiązaniach oraz zdolność adaptacji systemu do zmieniających się uwarunkowań społeczno-gospodarczych.

Do koncepcji resilient city jako systemu składającego się z wielu części odnosi się również definicja miasta autorstwa polskiego socjologa, pracownika Instytutu Filozofii i Socjologii PAN dr. hab. Aleksandra Wallisa, autora licznych prac badawczych z dziedziny socjologii. Według tej definicji miasto jest „złożonym z dwóch organicznie powiązanych na zasadzie sprzężeń zwrotnych, lecz autonomicznych podsystemów - urbanistycznego i społecznego”. Współczesne miasta są zatem „systemami złożonymi i wielopłaszczyznowymi (wielowymiarowymi), składającymi się z wielu elementów składowych" (Wallis, 1990).

Koncepcja miasta odpornego znajduje się również w obszarze zainteresowań współczesnych badaczy. Wskazać tu można prace m.in. dr. hab. Adama Drobniaka, prof. UE w Katowicach, który termin urban resilience tłumaczy jako „prężność miasta”, skupia się jednak głównie - w kontekście rozważań nad omawianym tematem - na aspekcie równowagi ekonomicznej współczesnych organizmów miejskich (Drobniak, Plac, 2015). Duży wkład w rozważania nad koncepcją urban resilience wnoszą prace innego współczesnego badacza - dr hab. Rafała Czachora, prof. KAAFM, według którego mówiąc o mieście odpornym, „przede wszystkim można mówić o podsystemach systemu miejskiego” (Czachor, 2019), obejmującego wszystkie sfery funkcjonowania miasta. W swojej pracy pt. Koncepcja urban resilience: założenia, treść, możliwości implementacji prof. Czachor wskazuje, że aby mówić o mieście jako pewnym powiązanym systemie, przede wszystkim należy zdefiniować i wskazać jego części składowe oraz określić obszary (określone w tej pracy jako podsystemy), które go tworzą, w szczególności: środowiskowo-przyrodniczy, gospodarczy, administracyjno-polityczny, społeczno-kulturowy. Na tej podstawie w artykule sformułowano zasadnicze pytania - do jakich zagrożeń i o jakim charakterze winna odnosić się „odporność" miasta, w jakich okolicznościach występuje oraz przy użyciu jakich środków można ją wzmacniać?

Czym więc powinno charakteryzować się miasto odporne? Współczesne resilient city to przede wszystkim miasto odporne na:

- klęski żywiołowe oraz ekstremalne zjawiska pogodowe,

- zmiany klimatyczne,

- rewolucje społeczne, polityczne i gospodarcze,

- ataki terrorystyczne,

- zagrożenia epidemiczne.

Mając na uwadze zdefiniowane powyżej zagrożenia oraz potrzeby współczesnej społeczności, konieczne jest wdrożenie w procesie rozwoju i ewolucji danego miasta działań wielopłaszczyznowych, mających na celu realizację najbardziej pożądanych cech „miasta odpornego", wśród których wskazać należy: 
- konieczność wprowadzenia zrównoważonego rozwoju i racjonalnego planowania przestrzennego,

- wdrażanie nowych, inteligentnych technologii w budownictwie i infrastrukturze,

- budowę infrastruktury technicznej i komunikacyjnej,

- wdrażanie rozwiązań mających na celu ochronę środowiska i działania proekologiczne,

- wykorzystanie lokalnych zasobów, samowystarczalność,

- racjonalną gospodarkę lokalnymi zasobami wodnymi i retencję wody opadowej,

- energooszczędność.

\section{KRAKÓW JAKO PRZYKŁAD MIASTA DĄŻĄCEGO DO MIEJSKIEJ ODPORNOŚCI}

Przykładem ewolucji współczesnego miasta, polegającej na wdrażaniu procesów, mających na celu zrównoważony rozwój, realizację potrzeb społeczno-gospodarczych populacji miasta oraz funkcjonujących na jego obszarze podmiotów jest trwający w zasadzie od czasów powojennych rozwój miasta Krakowa. Jako miasto o kilkusetletniej historii, podlegające na przestrzeni wieków organicznej rozbudowie, charakteryzuje się ono wyraźny podział na strefy, począwszy od strefy historycznej po nowe dzielnice, które charakteryzują się zróżnicowaną strukturą zabudowy (il. 2).

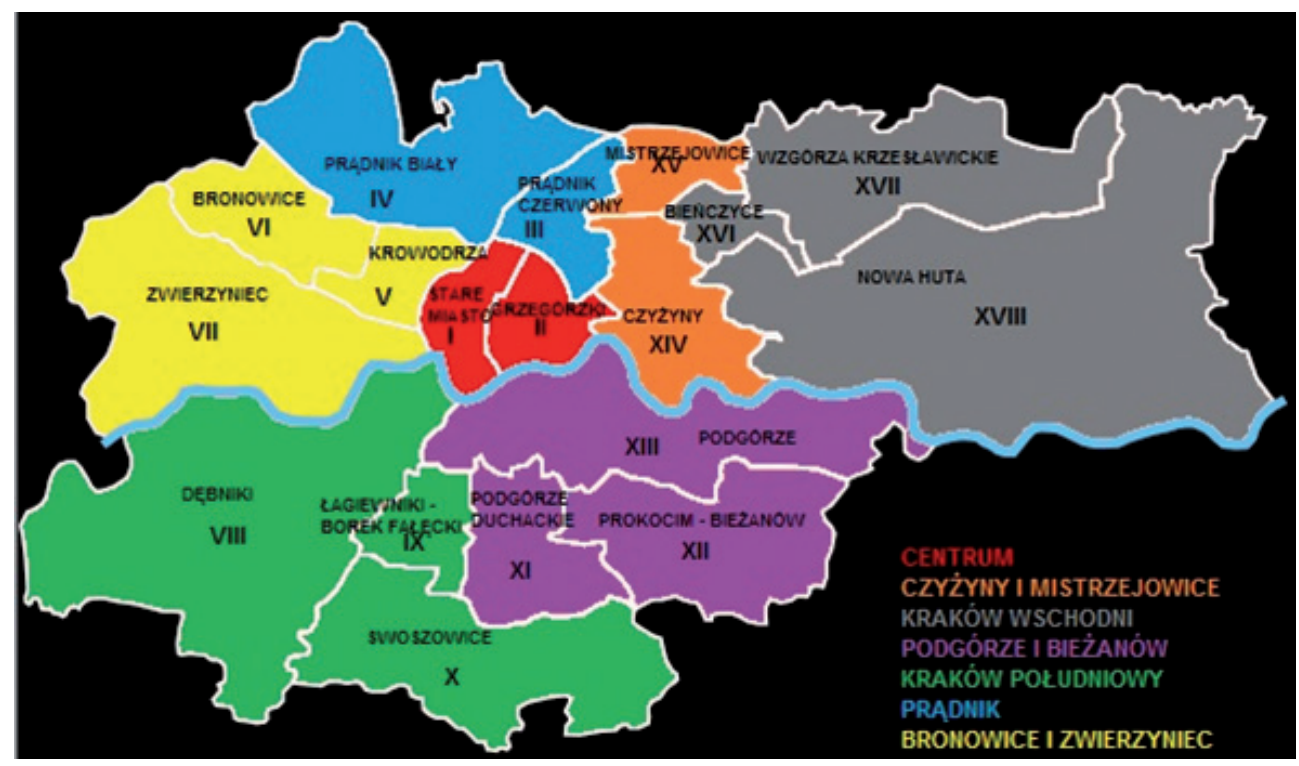

II. 2. Dzielnice miasta Krakowa - podział administracyjny (news.krakow.pl) 
Pierwszą strefę stanowi strefa historyczna - obejmująca historyczną zabudowę miasta, powstałą przed II wojną światową, w skład której wchodzą: Stare Miasto, Grzegórzki, Krowodrza, Podgórze. W strefie tej dominuje typ zabudowy historycznej, przeważającą większość tkanki historycznej części miasta stanowi zabudowa śródmiejska, składająca się z budynków wielorodzinnych w przeważającej części w zabudowie pierzejowej, jak również w zabudowie wolnostojącej.

Kolejną wyodrębnioną strefą jest zabudowa powstała w okresie po II wojnie światowej - tworzą ją „nowe” dzielnice miasta, w skład których wchodzą: Nowa Huta, Prokocim-Bieżanów, Bronowice, Prądnik, Dębniki, Czyżyny/Mistrzejowice. W strefie tej dominuje typ zabudowy wielorodzinnej, w większości o wysokiej intensywności.

Trzecią wyraźnie wykształconą strefę stanowią peryferyjne dzielnice miasta - Łagiewniki, Swoszowice, Zwierzyniec, oraz gminy ościenne, w których dominujący typ zabudowy stanowi zabudowa niska o niskiej intensywności.

Na obszarze miasta Krakowa funkcjonuje istniejąca i wciąż rozbudowywana infrastruktura komunikacyjna, obejmująca główne ciągi komunikacyjne oraz drogi lokalne, a potrzeby mieszkańców miasta zaspokaja transport publiczny i transport prywatny.

Zasoby mieszkaniowe miasta obsługiwane są przez rozbudowaną infrastrukturę komunalną - na terenie miasta zaopatrzenie w wodę i gospodarkę ściekami obsługują spółki miejskie, natomiast gospodarka odpadami obsługiwana jest zarówno przez spółki miejskie, jak i podmioty prywatne.

Zasoby mieszkaniowe Krakowa tworzy głównie zabudowa wielorodzinna, w przeważającej części komunalna oraz spółdzielcza, jak również zabudowa mieszkalna realizowana przez podmioty prywatne - według BIP Kraków (BIP Kraków, ???) w zasobach mieszkaniowych miasta znajduje się 265 tys. mieszkań o łącznej powierzchni 14,12 $\mathrm{mln} \mathrm{m}^{2}$.

Na terenie aglomeracji krakowskiej zabudowa wielorodzinna stanowi ok. 30\% ogólnej liczby budynków, w tym 90\% ogólnej liczby mieszkań. Zabudowa jednorodzinna, zlokalizowana głównie na obrzeżach miasta, stanowi natomiast 70\% ogólnej liczby budynków, w tym $10 \%$ ogólnej liczby mieszkań.

Według statystyk urzędowych przy istniejących zasobach mieszkaniowych przeciętna liczba osób przypadających na jedno mieszkanie wynosi 2,63 , a na jedną izbę 0,85 . Mimo to Kraków od lat wciąż boryka się z deficytem zasobów mieszkaniowych, co skutkuje wzrostem cen lokali mieszkalnych. Skutkiem tego deficytu, jak również ze względu na kurczące się zasoby gruntów znajdujących się w zasobach miejskich, a kwalifikujących się pod zabudowę, już w latach 90. ubiegłego stulecia, w okresie po transformacji ustrojowej i gospodarczej, rozpoczęła się eksplozja urbanistyczna oraz ekspansja zabudowy mieszkaniowej na obrzeża Krakowa i na tereny gmin ościennych. Efektem tego nieuniknionego w ówczesnej rzeczywistości procesu było tworzenie się enklaw zabudowy jednorodzinnej na peryferiach miasta i na terenach gmin sąsiadujących. 


\section{STREFA PODMIEJSKA W PROCESIE BUDOWANIA MIASTA ODPORNEGO}

Proces ekspansji na tereny suburbiów stanowił również odpowiedź na potrzebę poprawy dotychczasowych warunków mieszkaniowych, wynikającą głównie ze zmian, jakie zaszły w strukturze społeczeństwa. W związku ze zmianami społeczno-gospodarczymi, które zaszły na przestrzeni ostatnich dekad, a dzięki którym nastąpiło znaczne wzbogacenie się społeczeństwa, nastąpił masowy exodus mieszkańców „blokowisk” na tereny podmiejskie. Proces ten, trwający od przeszło trzech dekad, przyniósł również zauważalne zmiany zachodzące w społeczeństwie miasta - strefa podmiejska przestaje być już tylko „sypialnią” współczesnego miasta, a zaczyna tworzyć odrębny, autonomiczny organizm. Wynika to głównie ze zmiany systemu i filozofii pracy - coraz częściej dominuje praca nienormowana oraz praca zdalna, które nie wymagają ciągłego, codziennego przemieszczania się mieszkańców z terenów podmiejskich do centrum miasta.

Budowa enklaw podmiejskiej zabudowy mieszkaniowej stanowi więc niejako przyczynek do procesu budowy społeczności lokalnych, ale też - poniekąd przy okazji - realizacji idei miasta odpornego. Powstawanie enklaw zabudowy mieszkaniowej na obrzeżach miasta jednocześnie bowiem generuje i wymusza budowę i rozwój niezbędnej infrastruktury - komunikacyjnej (połączenia przedmieście-centrum miasta, połączenia lokalne), jak również technicznej, zarówno centralnej (rozbudowa miejskich sieci energetycznych i gazowych), jak i lokalnej (sieci wodociągowe zasilane ze źródeł lokalnych oraz kanalizacyjne - oparte głównie na lokalnych rozwiązaniach, np. realizowane w gminach ościennych oczyszczalnie ścieków, obsługujące rozrastającą się tkankę podmiejską).

Konsekwencją tego procesu są również istotne zmiany dotychczasowej struktury zabudowy i pojawienie się nowych (w naszej rzeczywistości) typów zabudowy podmiejskiej - na terenach podmiejskich dominuje bowiem głównie zabudowa mieszkaniowa o niskiej intensywności: zabudowa szeregowa, bliźniacza i (rzadziej) wolnostojąca, realizowana w wydzielonych, kameralnych zespołach mieszkaniowych II. 3). Ten typ zabudowy umożliwia wdrażanie pożądanych cech tkanki miasta odpornego, charakteryzuje go bowiem:

1) Zwartość zabudowy pozwalająca na maksymalne wykorzystanie terenów inwestycyjnych - zmniejszający się wciąż zasób oraz stale rosnące ceny gruntów kwalifikujących się pod zabudowę w terenach podmiejskich, czyli gruntów posiadających dostęp do niezbędnej infrastruktury, wymusiły racjonalizację procesu projektowania nowej zabudowy mieszkaniowej poprzez wprowadzanie bardziej zwartych typów zabudowy (np. zabudowy bliźniaczej lub szeregowej), realizowanej w większości - z przyczyn ekonomicznych - z zastosowaniem tzw. projektów typowych. Podmioty i inwestorzy realizujący zespoły zabudowy mieszkaniowej na terenach podmiejskich, kierując się ekonomiką inwestycyjną, w planowanych inwestycjach wykorzystują do maksimum określone w planach miejscowych parametry zabudowy (jak np. wskaźnik intensywności zabudowy, powierzchni zabudowy, powierzchni biologicznie czynnej), co umożliwia racjonalne wykorzystanie 
dostępnych zasobów gruntów budowlanych oraz pozwala na znaczące obniżenie kosztów inwestycji, a co za tym idzie - również cen nowo realizowanej zabudowy mieszkaniowej, co umożliwia jej dostępność dla osób posiadających mniejszą zdolność finansową (kredytową). Jednocześnie proces ten przyczynia się do ekspansji ludności z miasta na tereny strefy podmiejskiej, co prowadzi do „odciążenia” centrum miasta i poprawy warunków bytowych jego mieszkańców.

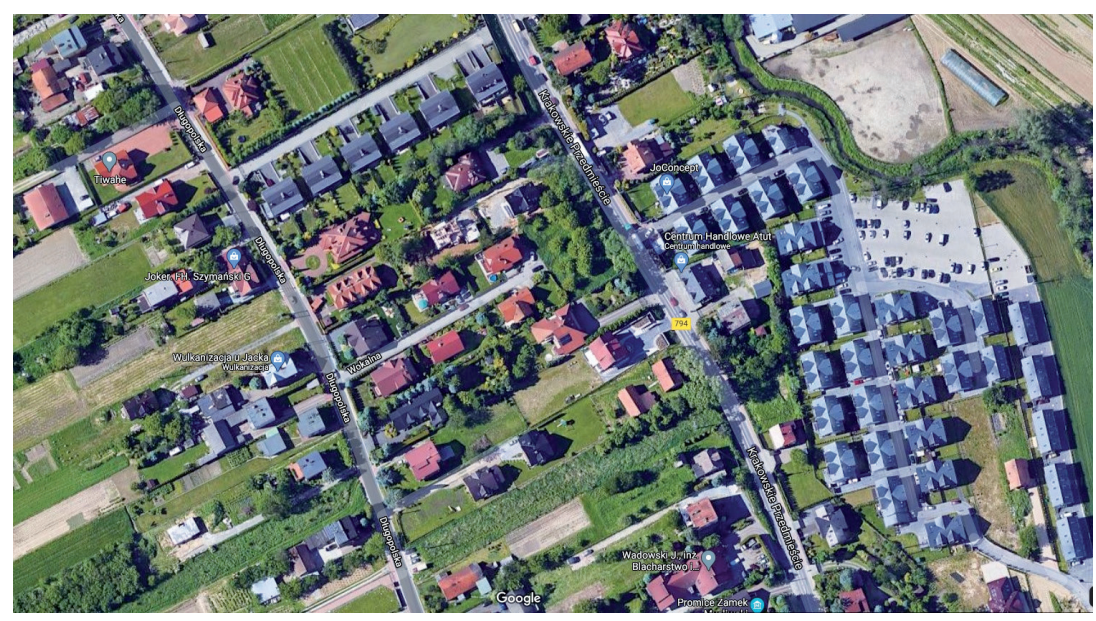

II. 3. Kształtowanie się tkanki podmiejskiej - indywidualna zabudowa jednorodzinna vs. zorganizowane zespoły mieszkaniowe (Google Maps)

2) Kompaktowanie zabudowy strefy podmiejskiej, stanowiące istotny czynnik umożliwiający porządkowanie i organizowanie przestrzeni podmiejskiej, również podyktowane jest koniecznością racjonalnego wykorzystania stale zmniejszających się zasobów gruntów budowlanych w strefie podmiejskiej oraz na obszarze gmin ościennych. W wyniku zachodzących obecnie zmian społecznych i gospodarczych, skutkujących modyfikacją modelu współczesnej rodziny $(2+2,2+3)$, konieczne stało się dostosowanie nowo realizowanej zabudowy mieszkaniowej do rzeczywistych potrzeb społecznych i możliwości ekonomicznych społeczeństwa.

W projektowanej obecnie w strefie podmiejskiej zabudowie mieszkaniowej przeważają zatem domy przystosowane do potrzeb cztero- lub pięcioosobowej rodziny. Mając na uwadze zarówno możliwości ekonomiczne, jak również rzeczywiste potrzeby przeciętnej polskiej rodziny, w strefie podmiejskiej projektuje się obecnie i realizuje zabudowę organizowaną przeważnie w zwartych zespołach mieszkaniowych (w zabudowie bliźniaczej lub szeregowej), co zarówno umożliwia zaspokojenie rzeczywistych potrzeb współczesnej rodziny, jak również pozwala na racjonalne - uwzględniające przede wszystkim aspekty gospodarcze - wykorzystanie i organizowanie przestrzeni urbanistycznej (il. 4). 


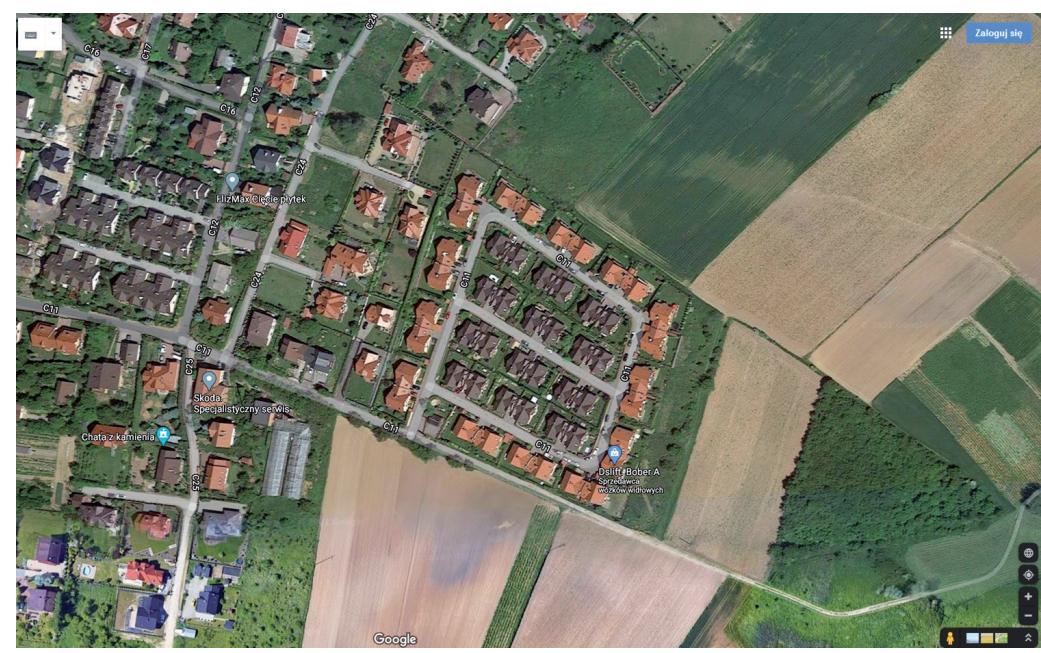

II. 4. Zorganizowane zespoły mieszkaniowe na peryferiach miasta jako przykład porządkowania przestrzeni podmiejskiej (Google Maps)

Ten typ zabudowy, realizowany głównie przez prywatne podmioty, dzięki maksymalnemu wykorzystaniu określonych w planach miejscowych parametrów zagospodarowania oraz dzięki minimalizacji kosztów realizacji (zastosowanie typowych rozwiązań i projektów gotowych, racjonalizacja kosztów procesu budowlanego) umożliwia realizację potrzeb społecznych w zakresie dostępności zabudowy mieszkaniowej, a także sprzyja racjonalnemu organizowaniu przestrzeni oraz wykorzystaniu dostępnych zasobów gruntów budowlanych (il. 5).

3) Zorganizowany i racjonalny rozwój układu komunikacyjnego, stanowiącego „krwioobieg" współczesnych organizmów miejskich poprzez powiązanie terenów podmiejskich z centrum miasta - proces dynamicznej urbanizacji terenów podmiejskich - wymusza konieczność przebudowy i modernizacji istniejącej sieci komunikacyjnej, jak również generuje potrzebę jej rozbudowy o nowe połączenia drogowe, umożliwiające obsługę komunikacyjną terenów podmiejskich, na których realizowana jest nowa zabudowa mieszkaniowa. Przyczynia się to do poprawy drożności miejskiego układu komunikacyjnego, odciążając główne arterie komunikacyjne miasta poprzez przeniesienie części ruchu na drogi lokalne. Proces rozbudowy i modernizacji układu drogowego miasta i jego połączenia z tkanką mieszkaniową strefy podmiejskiej realizują założenia miasta odpornego, przyczyniając się jednocześnie do poprawy warunków życia jej mieszkańców. Jednocześnie zauważyć należy, iż w procesie tym oraz podczas ponoszeniu jego kosztów winny uczestniczyć nie tylko lokalne społeczności (w szczególności - administracje), ale również - w ramach partnerstwa publiczno-prywatnego - jego rzeczywiści beneficjenci, czyli podmioty realizujące zabudowę mieszkaniową w ramach prowadzonej działalności. 


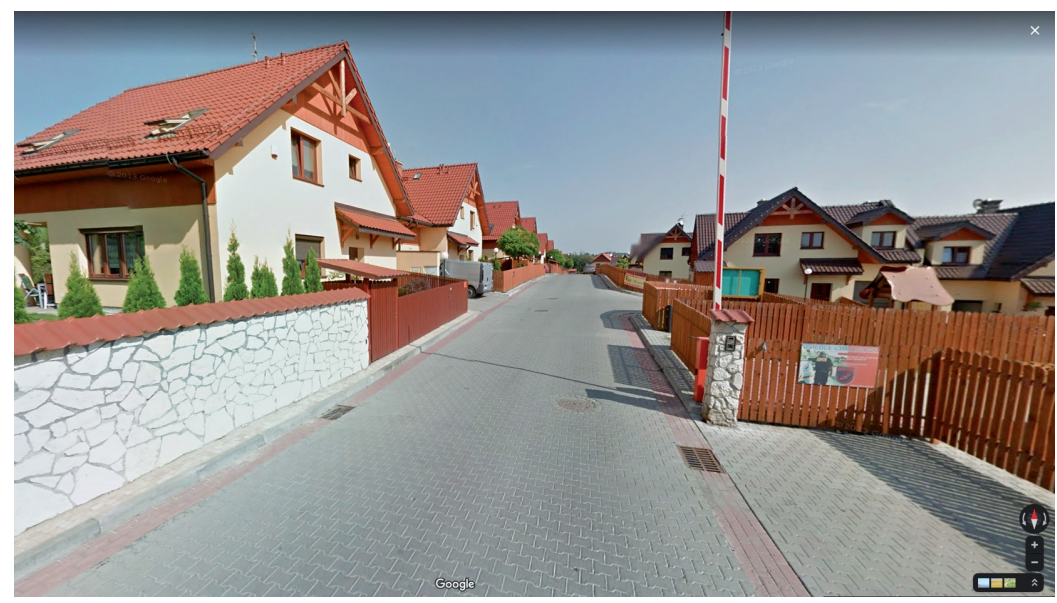

II. 5. Zwarta zabudowa podmiejska jako przykład racjonalnego wykorzystania przestrzeni (Google Maps)

4) Samowystarczalność dzięki zasobom lokalnym, w szczególności w zakresie zaopatrzenia w wodę i gospodarki ściekowej, oraz możliwość wprowadzania OzE - który to czynnik konieczny jest do zachowania lokalnej równowagi ekonomicznej oraz ekologicznej - wynikają z założeń budowy miasta odpornego i są efektem rozrastania się tkanki zabudowy mieszkaniowej miejskiej na tereny podmiejskie. Projektowanie i realizowanie na terenach podmiejskich zespołów zabudowy mieszkaniowej prowadzi bowiem do znaczącego wzrostu zapotrzebowania w zakresie zaopatrzenia w wodę oraz źródła energii, które miałyby zasilać nowo realizowaną zabudowę. Proces powstawania nowych zespołów zabudowy mieszkaniowej na terenach podmiejskich i obszarze gmin ościennych prowadzi do konieczności zarówno rozbudowy i modernizacji istniejących sieci wodociągowych, elektrycznych i gazowych, jak również wdrożenia rozwiązań funkcjonujących dzięki lokalnym zasobom. Bezsprzecznie - z przyczyn ekonomicznych - korzystniej jest bazować na nich i na lokalnej infrastrukturze (np. lokalnych ujęciach wody i sieciach wodociągowych, czy też sieciach kanalizacyjnych z odprowadzeniem do lokalnych oczyszczalni ścieków) niż rozbudowywać infrastrukturę miejską, mając na celu przyłączenie i zasilenie projektowanej i realizowanej na terenach podmiejskich zabudowy. Proces powstawania nowej zabudowy umożliwia również wprowadzanie nowoczesnych rozwiązań, umożliwiających pozyskiwanie energii niezbędnej do funkcjonowania zarówno nowo realizowanych, jak również istniejących obiektów. Przykładem może być możliwość stosowania indywidualnych źródeł pozyskiwania energii elektrycznej lub cieplnej poprzez zastosowanie np. paneli fotowoltaicznych czy paneli słonecznych. Rozwiązania te coraz częściej stosowane są - pomimo znacznych koszów - przez podmioty realizujące nową zabudowę mieszkaniową na terenach podmiejskich. 
5) Energooszczędność, będąca wynikiem proekologicznych działań legislacyjnych, jest równie istotnym czynnikiem przyczyniającym się do racjonalizacji i obniżenia kosztów utrzymania nowo realizowanych obiektów budowlanych - zarówno zabudowy mieszkaniowej, jak również towarzyszącej jej zabudowy usługowej. Wprowadzanie w projektach nowej zabudowy, realizowanych głównie na podstawie sprawdzonych rozwiązań projektów powtarzalnych, oraz w systemach grzewczych nowo realizowanych budynków nowoczesnych rozwiązań i technologii w zakresie termoizolacji umożliwia w dalszej perspektywie znaczne obniżenie zapotrzebowania na energię, co skutkować będzie istotnym obniżeniem kosztów ich funkcjonowania i utrzymania. Ponadto obniżenie zapotrzebowania na energię (zarówno elektryczną, jak również grzewczą) nowo realizowanych obiektów odciąży istniejącą infrastrukturę i umożliwi zasilenie większej liczby projektowanych obiektów.

6) Lokalna retencja i zarządzanie wodą opadową, która umożliwia racjonalizację lokalnej gospodarki wodnej poprzez gromadzenie, zagospodarowanie i lokalne wykorzystanie wód opadowych. Proces ten wspierany jest obecnie przez programy „małej retencji”, wprowadzające możliwość dofinansowania przez jednostki administracji lokalnej budowy indywidualnych zbiorników retencyjnych, umożliwia gromadzenie, zagospodarowanie i wykorzystanie wody opadowej, prowadząc w efekcie do pewnej samowystarczalności w skali lokalnej w zakresie zasobów wodnych - która realizuje w pewnym stopniu założenia miasta odpornego - oraz racjonalizacji ich eksploatacji, co prowadzi do znaczących oszczędności lokalnych zasobów.

\section{PROJEKT TYPOWY JAKO BUDULEC ODPORNEJ STREFY PODMIEJSKIEJ}

Proces powstawania enklaw zabudowy mieszkaniowej w strefie podmiejskiej Krakowa w chwili obecnej ulega znacznemu przyspieszeniu w związku z kurczącymi się w dużym tempie zasobami gruntów budowlanych (a właściwie - kwalifikujących się pod zabudowę). Faktem jest też, iż realizowana obecnie - głównie przez podmioty prywatne - na obrzeżach Krakowa i na terenie gmin sąsiadujących zabudowa podmiejska o niskiej intensywności w większości przypadków opiera się na projektach typowych. Projekty takie posiadają zarówno wady, jak i zalety - stanowią zarówno szansę, jak i niosą pewne zagrożenia dla zabudowy mieszkaniowej, realizowanej na ich podstawie.

Do zalet projektów typowych zaliczyć można w pierwszym rzędzie okres trwania samego procesu projektowego i inwestycyjnego, który w przypadku zastosowania projektu „gotowego" skrócony jest do koniecznego minimum, jak również koszt przygotowania inwestycji (tab. 1). Istotną zaletą projektów typowych jest również ich wielowariantowość, dająca inwestorowi możliwość doboru optymalnego dla niego rozwiązania. Projekty powtarzalne, wielokrotnie realizowane, to również wielokrotnie sprawdzone rozwiązania architektoniczne i konstrukcyjne, niwelujące do minimum ryzyko błędu projektanta, oraz wielokrotnie sprawdzone technologie. 
Tabela 1. Porównanie kosztów projektu indywidualnego i projektu typowego. Aut. DOMIPORTA

\begin{tabular}{|l|c|c|c|c|}
\hline \multirow{2}{*}{ Wydatki } & \multicolumn{2}{|c|}{$100-150 \mathbf{~ m}^{2}$} & \multicolumn{2}{c|}{$\mathbf{1 0 0 - 2 0 0 \mathbf { m } ^ { 2 }}$} \\
\cline { 2 - 5 } & $\begin{array}{c}\text { Projekt } \\
\text { indywidualny }\end{array}$ & $\begin{array}{c}\text { Projekt } \\
\text { katologowy }\end{array}$ & $\begin{array}{c}\text { Projekt } \\
\text { indywidualny }\end{array}$ & $\begin{array}{c}\text { Projekt } \\
\text { katologowy }\end{array}$ \\
\hline Koszt projektu & $5000-22500$ PLN & $800-4000$ PLN & 7500-30 000 PLN & 2400-3600 PLN \\
\hline Mapa geodezyjna & 1000 PLN & 1000 PLN & 1000 PLN & 1000 PLN \\
\hline $\begin{array}{l}\text { Badania } \\
\text { geotechniczne } \\
\text { gruntu } \\
\text { (opcjonalnie) }\end{array}$ & $1200-2000$ PLN & $1200-2000$ PLN & $1200-2000$ PLN & $1200-2000$ PLN \\
\hline $\begin{array}{l}\text { Adaptacja } \\
\text { projektu }\end{array}$ & nie dotyczy & $1500-2500$ PLN & nie dotyczy & $1500-2500$ PLN \\
\hline Razem & $6000-25500$ PLN & $3300-8500$ PLN & $8500-33000$ PLN & $4900-9100$ PLN \\
\hline
\end{tabular}

Wadą i zagrożeniem, które niesie stosowanie projektów typowych, jest możliwość pozbawienia tożsamości lokalnej danego miejsca poprzez wprowadzenie nowej architektury i nowych typów zabudowy w istniejącej, tradycyjnej tkance urbanistycznej, jak również brak różnorodności, unifikacja zabudowy i „nijakość” architektury. Projekt typowy niejednokrotnie też stanowi trudny kompromis pomiędzy rzeczywistymi potrzebami inwestora a realnymi kosztami inwestycji.

Rozważając zalety i wady realizacji zespołów mieszkaniowych z zastosowaniem projektów typowych (gotowych) nie można lekceważyć szans i możliwości, jakie niesie ze sobą to rozwiązanie - skrócenie procesu projektowego i inwestycyjnego do minimum bez wątpienia przyczynia się do dynamicznego rozwoju rynku budownictwa mieszkaniowego, jak również daje możliwość projektowania budynków i zespołów budynków typowych, czy też modularnych/prefabrykowanych.

Projekty typowe, projektowane i planowane do sprzedaży w zwiększonych nakładach, stanowią też niejako narzędzie do wprowadzania pożądanych rozwiązań - dających jednocześnie możliwość realizacji założeń i koncepcji miasta odpornego, do których zaliczyć należy:

- wymuszoną wymaganiami rynku i zmianami w prawie ewolucję projektów typowych, która stanowi swoisty poligon do wprowadzania nowych technologii przy stosunkowo niskich kosztach opracowania,

- uniwersalność projektów typowych umożliwiającą tworzenie różnych wariantów stylistycznych na bazie jednego układu funkcjonalnego,

- energooszczędność budynku w projektach typowych stanowiącą priorytet i bezwzględny wymóg,

- funkcjonalność budynku oraz racjonalność konstrukcji stanowiące podstawową zasadę projektowania,

- osiągnięcie maksimum samowystarczalności dzięki maksymalnemu wykorzystaniu lokalnych zasobów, 
- kompaktowość umożliwiającą racjonalne i uporządkowane organizowanie przestrzeni strefy podmiejskiej z możliwością tworzenia na bazie projektów powtarzalnych jednolitej zabudowy w kameralnych zespołach mieszkaniowych.

\section{PODSUMOWANIE I WNIOSKI}

Odpowiadając na zadane na wstępie pytania - czy w świetle specyfiki procesów rozwoju miasta, analizowanych na przykładzie Krakowa, projekty typowe stanowić mogą szansę, czy też zagrożenie dla realizacji zabudowy obszarów na obrzeżach miast, jak również czy wpisują się w urzeczywistnienie idei miast odpornych - można stwierdzić, że umiejętnie - czyli racjonalnie (w szczególności - pod względem ekonomiki procesu budowlanego) i funkcjonalnie zaprojektowane i wprowadzone na rynek typowe rozwiązania projektowe mogą przyczynić się do budowania miejskiej rezyliencji. Dzięki możliwości zastosowania w projektach powtarzalnych rozwiązań zrównoważonych, uwzględniających ich potencjał dostosowania do lokalnych uwarunkowań i wykorzystania miejscowych zasobów oraz poprzez wprowadzanie nowoczesnych technologii powstające na bazie powtarzalnych projektów budynki mogą przyczyniać się do realizacji idei miasta odpornego poprzez oszczędność energii, racjonalne wykorzystanie lokalnych zasobów, jak również ochronę miejscowych zasobów wodnych (w szczególności poprzez możliwość zagospodarowania i retencji wód opadowych), dzięki czemu mogą być one samowystarczalne i - w pewnym zakresie - neutralne dla środowiska.

Warunkiem podstawowym jest przede wszystkim wprowadzenie przez lokalne władze racjonalnej i zrównoważonej polityki planowania przestrzennego, ułatwiającej w szczególności modernizację i rozbudowę miejskiego systemu komunikacyjnego - z uwzględnieniem jego powiązań ze strefą podmiejską - oraz transportu lokalnego, jak również narzucającej w procesie urbanizacji terenów podmiejskich konieczność przeznaczania części terenu pod przestrzenie społeczne i publiczne, co umożliwi i ułatwi proces integracji lokalnych społeczności. Również prowadzona przez lokalne władze polityka społeczna i gospodarcza - w powiązaniu z polityką przestrzenną - winna wspierać rozwój i rozbudowę zrównoważonej infrastruktury oraz promować takie rozwiązania ekonomiczne, które poprzez np. wspieranie preferencyjnych kredytów mieszkaniowych dla lokalnej społeczności czy też wprowadzenie systemu dofinansowania premiującego inwestorów realizujących dobrze i racjonalnie zaprojektowane nowoczesne zespoły mieszkalne przyczyniać się mogą do wzmocnienia rezyliencji współczesnego miasta. 


\section{BIBLIOGRAFIA}

BIP Kraków. (b.r.). Zasoby i tereny mieszkaniowe oraz infrastruktura społeczna. Pobrane z: https://www.bip.krakow.pl (dostęp: 08.06.2021).

Czachor, R. (2019). Koncepcja urban resilience: założenia, treść, możliwość implementacji. Społeczności Lokalne. Studia Interdyscyplinarne, 3, 127-148.

Drobniak, A. (2018). Rezyliencja i hybrydyzacja rozwoju małych i średnich miast w Polsce. Katowice: Uniwersytet Ekonomiczny.

Drobniak, A., Plac, K. (2015). Urban Resilience - transformacja miast poprzemysłowych aglomeracji Górnośląskiej. Studia Ekonomiczne, 250, 75-98.

Jania, A. (2018). Kształtowanie konkurencyjności tkanki miejskiej pod wpływem projektów deweloperskich w kontekście koncepcji urban resilience. W: Ł. Fiedenia, K. Anielskiej, K. Listwan-Franczak, P. Franczak (pod red.), Współczesne problemy i kierunki badawcze w geografii (s. 83-99). Kraków.

Spiller, J. (2018). Miasto odporne na każdy kryzys. Pobrane z: www.teraz-srodowisko.pl (dostęp: 08.06.2021).

Świątek, L. (2015). Miasta spustoszone. Koncepcja rezyliencji w procesie rewitalizacji małych i średnich miast. Przestrzeń i Forma, 1(23), 117-128.

Wallis, A. (1990). Socjologia przestrzeni. Warszawa: Niezależna Oficyna Wydawnicza.

Wieteska-Rosiak, B. (2018). Hybrydyzacja przestrzeni publicznej miasta w kontekście adaptacji do zmian klimatu. Łódź: Uniwersytet Łódzki.

http://blog.globtroter-krakow.com/ (dostęp: 08.06.2021). news.krakow.pl (dostęp: 15.06.2021).

Google Maps (dostęp: 15.06.2021). 
